\title{
The Association between Viral Infections, Maternal and Fetal Mortality/Morbidity
}

\author{
Yasmin Neggers* \\ Department of Human Nutrition, University of Alabama, USA \\ Submission: March 05, 2018; Published: April 20, 2018 \\ *Corresponding author: Yasmin Neggers Department of human Nutrition, University of Alabama, USA, Tel: 205-887-0909; \\ Email: yneggers@ches.ua.edu
}

\begin{abstract}
Viral infections in pregnancy are a major cause of maternal and fetal mortality/morbidity. The viral infections of concern during pregnancy are caused by cytomegalovirus (CMV) rubella virus and herpes simplex virus (HSV). Other viruses now known to cause congenital infections include varicella-zoster virus (VZS), West Nile virus, measles virus, enterovirus, HIV and Zika virus. Also, hepatitis E is important because of its high mortality rate associated with infection during pregnancy. Mortality and morbidity from Cytomegalovirus and varicella -zoster virus are discussed.

Keywords: Virus; Infection; Pregnancy; Mortality; Morbidity; Fetus; Cytomegalovirus; Congenital infections; West Nile virus; Measles virus; Enterovirus; Zika virus; Hepatitis E; Pregnancy; Cardiovascular; Hemorrhage; Sepsis; Microcephaly; Neurological sequelae; Microcephaly; Thrombocytopenia; Congenital Varicella

Abbreviations : CMV: Cytomegalovirus; HSV: Herpes Simplex Virus; VZS: Varicella Zoster Virus; IgG: Immunoglobulin G; CVS: Congenital Varicella Syndrome
\end{abstract}

\section{Introduction}

Maternal and fetal mortality are of major global concern. The reduction of maternal deaths is a key international development goal. Given that at least half of maternal deaths in the U.S. are preventable, the rise in maternal deaths in the U.S. is historic and worrisome [1]. Causes of and risk factors for pregnancy-related deaths from 1987 to 2011 have already been published in the literature. Information on causes of pregnancy-related deaths occurring after 2005 have been released regularly on CDC's the website [2]. Current data show a decline in the contribution of the traditional causes of pregnancy-related deaths, i.e., hemorrhage, sepsis, hypertensive disorders of pregnancy and emergence of cardiovascular and other medical conditions such as infection or sepsis as important contributors to maternal mortality in United States [3]. Viral infections in pregnancy are major causes of maternal and fetal morbidity and mortality. Traditionally, the viral infections of concern during pregnancy were those caused by cytomegalovirus (CMV) rubella virus and herpes simplex virus (HSV) [4]. Other viruses now known to cause congenital infections include varicella-zoster virus (VZS), West Nile virus, measles virus, enterovirus, HIV and Zika virus. Also, hepatitis $\mathrm{E}$ is important because of its high mortality rate associated with infection during pregnancy. With emergence of an influenza pandemic, the effects of influenza during pregnancy are also important [5]. A detailed discussion of all the viral infections during pregnancy is beyond the scope of this commentary. Fetal morbidity and or maternal mortality resulting from Cytomegalovirus (CMV) and Varicella-zoster virus (VZV) will be briefly discussed here. CVM infection is the most common perinatal infection in the United States. CMV is a double stranded DNA herpes virus and its seropositivity rate increase with age. CMV infection requires intimate contact via urine, saliva and/or other body fluids. Possible routes of CMV infection mostly include sexual contact, trans placental transmission, transmission through breast milk and rarely by blood transfusion. Studies indicate that vertical transmission of CMV can occur at any stage of pregnancy. Most infections cause no symptoms, but approximately $10 \%$ result in symptoms like microcephaly, hydrocephalus, delayed psychomotor development and optic atrophy. Thirty percent of newborns with severe CMV infection die. Among survivors, more than half eventually develop neurological sequelae such as microcephaly, thrombocytopenia, IUGR, or a combination of these problems.

VZV is a common virus that can cause mortality and morbidity during pregnancy for both the mother and fetus. Morbidly and mortality rates associated with VZV infection are much higher in mothers than in infants. Varicella infection is so severe during pregnancy that it is considered a medical emergency [6]. Pneumonitis due to VZV infection is about 25 times more 
common in adults that in infants. The risk of life threatening ventilatory compromise, during the third trimester is high, with a mortality rate of $14 \%$. Pneumonitis during pregnancy carried a mortality rate of $45 \%$ before the development of antiretroviral [7]. Furthermore, Congenital Varicella Syndrome (CVS) causes spontaneous abortion, cataract, limb atrophy and or neurological disabilities. Infection in the mother in the perinatal period, specifically 5 days prior to delivery or 2 days afterward, poses a risk of severe neonatal varicella with a mortality rate of $30 \%$. Trans placental transfer of immunoglobulin $\mathrm{G}$ antibodies that prevent the development of maternal antibodies occurs during the infection in the perinatal period. Immunoglobulin G (IgG) confer passive immunity to the fetus [8].

\section{Conclusion}

It is evident that maternal viral infections can cause serious fetal and maternal morbidity/mortality. Early initiation of treatment is recommended for pregnant women, although there is some evidence that later treatment may still be beneficial. Research, including several clinical trials is under way to test the methodology and efficacy of treatments, and hence reduction in maternal and fetal morbidity/mortality due to viral infections

\section{References}

1. Neggers YH (2016) Trends in maternal mortality in the United States. Reprod Toxicol 64: 72-76.

2. www.cdc.gov/reproductivehealth/MaternalInfantHealth/PMSS.html

3. Ronsmans CA, Graham WJ (2006) Maternal mortality; who, when, where, and why. Lancet 386(9542): 1187-1200.

4. Centers for disease Control and Prevention (2013) Pregnancy- related Mortality Surveillance.

5. Marino T, Isaacs C (2017) Viral infection and pregnancy. Medscape 2: $1-21$.

6. Khan KS, Wojdyla D, Say L, Gülmezoglu AM, Van Look PF (2006) WHO analysis of causes of maternal death: a systematic review. Lancet 367(9516): 1066-1074.

7. Halder A, Viajselvi R, Jose R (2015) Changing perspective of infectious causes of maternal mortality. J Turk ger gynecol Assoc 16(4): 208-213.

8. Sahai S, Misra V, ganga D, Jatav OP (2015) Viral hepaptitis in pregnancy-A study of its effect on maternal and Foetal outcome. J Assoc Physicians India 63(1): 28-33.

Your next submission with Juniper Publishers
will reach you the below assets
- Quality Editorial service
- Swift Peer Review
- Reprints availability
- E-prints Service
- Manuscript Podcast for convenient understanding
- Global attainment for your research
- Manuscript accessibility in different formats
( Pdf, E-pub, Full Text, Audio)
- Unceasing customer service
Track the below URL for one-step submission
https://juniperpublishers.com/online-submission.php

